\title{
CONSTRUCTION ORGANIZATIONAL CULTURE IN GENDER PESANTREN THROUGH KIAI'S TRANSFORMATIONAL LEADERSHIP
}

\author{
Umiarso \\ Universitas Muhammadiyah Malang \\ Malang, Jawa Timur, 65144, Indonesia \\ Email:umiarso@umm.ac.id
}

Abd. Muhith

State Islamic Institue of Jember

Karang Miuwo, Mangli, Kaliwates, Jember, Jawa Timur 68136, Indonesia

Email:umiarso@umm.ac.id

\begin{tabular}{c|c|c}
\hline Received: & Revised: & Approved: \\
$27 / 03 / 2019$ & $17 / 06 / 2019$ & $27 / 30 / 2019$ \\
\hline
\end{tabular}

DOI: http:/ /dx.doi.org/10.32332/akademika.v24i1.1614

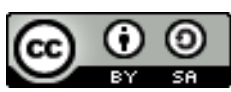

Construction Organizational Culture In Gender Pesantren Through Kiai"es Transformational Leadership Licensed Under a Creative Commons Attribution-ShareAlike 4.0 International License

\begin{abstract}
Through transformational leadership, pesantren are able to make institutional changes to achieve success. Because this leadership style can build a strong organizational culture for the effectiveness of Islamic education in pesantren. Therefore, KHMA in PNIA is very effective in carrying out the construction of pesantren culture and shapes the behavior of all pesantren human resources. Therefore, this research uses a qualitative approach with a phenomenological type; which aims to identify and analyze the kiai's transformational leadership style in building an organizational culture in pesantren. The theoretical framework used to analyze the dynamics of the kiai's leadership is the paradigm of Bass \& Riggio. He divided the four dimensions of transformational leadership, i.e: idealized influence, inspirational motivation, intellectual motivation, and individual consideration. This research found KHMA constructs pesantren
\end{abstract}


culture by taking from the thoughts of ulama' salaf which are contained in the book of salaf -which is commonly called Kitab Kuning. On the one hand, the effectiveness of KHMA's self-leadership in PNIA is also inseparable from the normative doctrinal values of Islam, so that the kiai's leadership style is based on Islamic values. The implication is that the construction of organizational culture ranging from a philosophical framework to the practical values of pesantren needs to be bound by the basis of social-religious transformation.

Keywords: Transformational Leadership, Kiai, and Organizational culture

\section{A. Introduction}

Leadership is one of the most studied organizational behaviors, 1including in education. ${ }^{2}$ As also conducted by Davis \& Thomas, ${ }^{3}$ Barth, ${ }^{4}$ Tobroni, ${ }^{5}$ Yunus, ${ }^{6}$ Raihani,7 Zamroni \& Umiarso, ${ }^{8}$ Hidayah, ${ }^{9}$ Money, ${ }^{10}$ Crowne, ${ }^{11}$ or Munir \& Aboidullah. ${ }^{12}$ This proves that leadership aspect

1 Stephen P Robbins dan Mary Coulter, Management. New Jersey: Prentice Hall., 2012, 460; Stephen P Robbins, Organizational Behavior (New Jersey: Prentice Hall, 2001), 413; Shaun Tyson dan Tony Jackson, The Essence of Organizational Behaviour: Perilaku Organisasi, Peterj.: Deddy Jacobus \& Dwi Prabantini (Yogyakarta: Andi, 2009), 83; Veithzal Rivai, Kepemimpinan dan Perilaku Organisasi (Jakarta: Rajawali Pers, 2008), 2.

2 Jaap Scheerens (Edit.), School Leadership Effects Revisited: Review and MetaAnalysis of Empirical Studies (New York: Springer, 2012), 11.

${ }^{3}$ Gary F Bell, "Indonesia: The Challenges of Legal Diversity and Law Reform," in E. Ann Black, Gary F. Bell (eds.). Gary F. Bell. Law and Legal Institutions of Asia: Traditions, Adaptations and Innovations (New York: Cambridge University Press, 2011).

${ }^{4}$ Ronald S Barth, Improving School from Within. San Francisco: Jossey-Bass., 1990.

5 Tobroni, The Spiritual Leadership: Pengefektifan Organisasi Noble Industry Melalui Prinsip-Prinsip Spiritual Etis (Malang: UMM Press, 2005).

${ }^{6}$ Jamal Lulail Yunus, Leadership Model: Konsep Dasar, Dimensi Kerja, dan Gaya Kepemimpinan (Malang: UIN Malang Press, 2009).

7 Raihani, Kepemimpinan Sekolah Transformatif (Yogyakarta: LKiS, 2010).

8 Zamroni, ESQ Model \& Kepemimpinan Pendidikan: Konstruksi Sekolah Berbasis Spiritual (Semarang: RaSAIL., 2011).

${ }_{9}$ Nurul Hidayah, Kepemimpinan Visioner Kepala Sekolah dalam Meningkatkan Mutu Pendidikan, (Yogyakarta: Ar-Ruzz Media, 2016).

${ }^{10}$ Nurul Hidayah, Kepemimpinan Visioner Kepala Sekolah dalam Meningkatkan Mutu Pendidikan (Yogyakarta: Ar-Ruzz Media, 2016).

11 Kerri Anne Crowne, "Investigating Antecedents of Transformational Leadership in Students" 12, no. (1) (2019): 80-94. 
becomes an important part in the world of education. Leadership is a very complex process as a result of interaction between leaders, subordinates (followers), and background situation. ${ }^{13}$ It is natural if researchers and academics strive to "unravel" the mystery behind the success of great leaders by bringing up a variety of perspective views. This framework brings out theories like trait and behavioral theories in which there are two popular studies from Ohio State Studies and the University of Michigan Studies, as well as contingency theories.

This description shows that the key success of educational institutions lies in its leadership aspect. ${ }^{14}$ In fact, in the twenty first century, the public recognizes the importance of leadership in the operations of educational institutions. Moreover, the quality of leadership has proven to be a significant distinguishing indicator between educational institutions and outcomes. $^{15}$ Factually, the quality of leadership is crucial to the achievement of the goals (vision and mission of education), characterized by the ability to manage educational organizations, influence others (subordinates) and team morale, and ability to cooperate. ${ }^{16}$ Thus, leadership has a high significance in providing changes to educational institutions.

Similarly, the leadership of Kiai in pesantren may influence the growth pattern and development of educational institution. As in the pattern of pesantren institution changes, ${ }^{17}$ pesantren business, ${ }^{18}$ pesantren financing, ${ }^{19}$

12 Farhat Munir dan Muhammad Aboidullah, "Gender Differences in Transformational Leadership Behaviors of School Principals and Teachers' Academic Effectiveness," 2018, 99-113, Bulletin of Education and Research.

${ }^{13}$ Afsaneh Nahavandi, The Art and Science of Leadership. (New Jersey: Prentice Hall, Inc., 2000), 153.

14 Michael Baptiste, "No Teacher Left Behind: The Impact of Principal Leadership Style on Teacher Job Satisfaction and Student Success, in Journal of International Education and Leadership 9 (1) 2019, 1-11.," t.t., 1-11; Bahar Agus Setiawan dan Abd Muhith, Transformational Leadership: Ilustrasi di Bidang Organisasi Pendidikan (Jakarta: Rajawali Pers, 2013), 5; Tatiana Melguizo dan Hamish Coates, "The Value of Assessing Higher Education Student Learning Outcomes" 3 (3) (2017): 1-2; Edward Sallis, Total Quality Management in Education (London: Kogan Page, 2002), 67.

${ }_{15}$ Tony Bush, Leadership and Management Development in Education (London: Sage Publishing, 2008).

${ }^{16}$ Abd Wahab dan Umiarso, Kepemimpinan Pendidikan dan Kecerdasan Spiritual (Yogyakarta: Ar-Ruzz Media, 2011).

17 Nur Efendi, Manajemen Perubahan di Pondok Pesantren: Konstruksi Teoritik dan Praktik Pengelolaan Perubahan sebagai Upaya Pewarisan Tradisi dan Menatap Tantangan Masa Depan (Yogyakarta: Teras, 2014). 
modernization of education and institution, ${ }^{20}$ or a change towards the political dynamics of pesantren. ${ }^{21}$ It means that kiai leadership has a wide impact, which is not only specified in small groups only. One of the impacts is the pesantren culture which, in macro scale, refers to the context of the values and norms of the organizational system. This dynamicity gradually led to some researches that focused their study on leadership correlations with organizational culture changes ${ }^{22}$ such as Mardiyah's research on Kiai leadership in maintaining organizational culture; ${ }^{23}$ or Alam research on strengthening leadership culture. ${ }^{24}$

As commonly occurred in any educational institution or other organization, the organizational culture in pesantren grows through an evolutive process, arising from the ideas or brilliant ideas of the leader -the

18 Siswanto, et. al, "Entrepreneurial Motivation in Pondok Pesantren" 3 (2) 2013 (t.t.): 42-54; Nur Khusniyah Indrawati, "Management by Inspiration: Implementation of Transformational Leadership on Business at Pondok Pesantren Sunan Drajat" 115 (2014): 79-90; Biyati Ahwarumi dan Tjiptohadi Sawarjuwono, "Enhancing Innovation Roles of Pesantren Business Incubator in Pondok Pesantren Sunan Drajat" 1 (2) (2017): 71-82.

19 Abu Choir, "Manajemen Entrepreneurship Berbasis Pesantren dalam Pengembangan Sumber Pembiayaan Pendidikan: Studi Multikasus pada Pondok Pesantren Maslakul Huda Kajen Margoyoso, Pondok Pesantren al-Isti'anah Plagitan Pati, dan Pondok Pesantren Manbaul Huda Kembang Dukuhseti Kabupaten Pati Jawa Tengah" (Universitas Islam Negeri Maulana Malik Ibrahim, 2016), Dissertation Summary.

${ }^{20}$ Ali Anwar, Pembaruan Pendidikan di Pesantren Lirboyo Kediri (Yogyakarta: Pustaka Pelajar, 2011).

${ }^{21}$ Endang Turmudi, Perselingkuhan Kiai dan Kekuasaan. (Yogyakarta: LKIS, 2003); Imam Suprayogo, Kyai dan Politik: Membaca Citra Politik Kyai (Malang: UINMalang Press, 2009); Achmad Patoni, Peran Kiai Pesantren dalam Partai Politik (Yogyakarta: Pustaka Pelajar, 2007); Saidin Ernas dan Ferry Muhammadsyah, "Dampak Keterlibatan Pesantren dalam Politik: Studi Kasus Pesantren di Yogyakarta" 25 (2) (2010): 195-224; Sukarno, Budaya Politik Pesanten Perspektif Interaksionisme Simbolik (Yogyakarta: Interpena, 2012), 195-224; Nurul Azizah, Artikulasi Politik Santri: Dari Kyai Menjadi Bupati (Yogyakarta: Pustaka Pelajar, 2013).

22 Mats Alvensson, Understanding Organizational Culture (London: Sage Publication, 2002).

23 Mardiyah, Kepemimpinan Kiai dalam Memelihara Budaya Organisasi (Yogyakarta: Aditya Media Publishing, 2012).

${ }^{24}$ Naufal Ahmad Rijalul Alam, "Strengthening Leadership Culture: The Role of Kyai in Indonesia Pesantren" 13 (1), no. 2018 (t.t.): 5-17. 
creative ideas of the Kiai-25 and followed by his followers. This framework by Robbin suggests that "when an organization takes on institutional permanence, acceptable modes of behavior becomes largely self-evident to its members". ${ }^{26}$ Therefore, the Kiai directs all human resources (pesantren's civitas) to participate in their actions or activities in order to maintain and build the pesantren. Kiai himself feels responsible for maintaining religious education, ${ }^{27}$ because he is the absolute source of power and authority in the life and environment of pesantren, ${ }^{28}$ owner ${ }^{29}$ or the king in the pesantren..$^{30}$ Therefore, in Siregar, et. al. research found that strong structure and pattern of Kiai leadership in pesantren will make the Kiai plays as the main character. ${ }^{31}$

However, in that context, the kiai's leadership style determines the effectiveness of the development of organizational culture. Especially when he faces certain situations with the character, behaviors and personality of pesantren that have been built and become a common perception held by the pesantren community. Therefore, the transformational leadership style as applied by KH. Muhyiddin Abdusshomad -then written KHMA- in pesantren Nurul Islam Antirogo -the written PNIA- is massively helpful in order to build pesantren culture and form the behavior of all pesantren civitas. It is in line with Mead \& Andrews statement, leadership style determines the effectiveness of organizational culture. ${ }^{32}$

${ }^{25}$ Khozin, "Pola Interaksi Pesantren dengan Lingkungan Sosialnya dalam Perspektif Sosio-Historis" 1 (1) (2016): 71-90.

26 Stephen P Robbins, Organizational Behavior, 510.

27 Nasaruddin Umar, Rethinking Pesantren (Jakarta: Kompas Gramedia, 2014), 47.

${ }^{28}$ Lihat Zamakhsyari Dhofir, Tradisi Pesantren: Studi tentang Pandangan Hidup Kyai, (Jakarta: LP3ES, 1994); Kamaruzzaman Bustamam-Ahmad, Islam Historis: Dinamika Studi Islam di Indonesia, (Yogyakarta: Galang Press, 2002, ) hal.65-82., t.t., 94.

${ }^{29}$ Sukamto, Kepemimpinan Kiai dalam Pesantren. (Jakarta: LP3ES, 1999), 1.

30 Bianca J Smith dan Mark Woodward(Edit.). ., Gender and Power in Indonesian Islam: Leaders, Feminists, Sufis and Pesantren Selves (London: Routledge, 2014).

31 Ferry Muhammadsyah Siregar, et. al., Religious Leader and Charismatic Leadership in Indonesia: The Role of Kyai Pesantren in Java, in Kawistara 3 (2) 2013, 117-226.

32 "Majalah US News, dalam edisinya terbaru menurunkan laporan panjang tentang perang pemikiran yang sedang diluncurkan Amerika Srikat. Dalam artikel yang diutlis oleh David E. Kaplan, diungkapkan bahwa pada front yang tersembunyi dalam perang melawan terorisme, Amerika membelanjakan jutaan dolar untuk mengubah wajah Islam. 'in an unseen front in the war on terrorism, America is spending millions to Change the Very Face of Islam'. (Huaim Hidayat, 
As for the implications, collective-collegial values and norms have significance for the life of socio-organization of PNIA. It formed normative values for pesantren civitas in understanding the various dynamics that occur in the pesantren environment. The result of its understanding eventually becomes a set of basic assumptions (paradigms) that are normative, interrelated and patterned, functioning as consultative values to handle important issues in pesantren's life. Consequently, according to Sopiah, the formulated values and norms will act as important means of creating harmonious working relationships in which common beliefs diminish opportunistic behavior. ${ }^{33}$

On one hand, the pesantren culture has a tremendous impact on the effectiveness of PNIA performance, which is based on Islamic religious values and norms. In general, the urgency of organizational culture role towards the performance and achievement of the organization has been recognized by many experts such as Robbins ${ }^{34}$ and Deal \& Kennedy. ${ }^{35}$ Research results show that organizational effectiveness demands a strong culture built of core beliefs, core values, vision and mission that can be both paradigm and driving force for change. ${ }^{36}$ Similarly, a research conducted by Kotter \& Heskett proves that profit organizations that have high economic performance cannot be separated from the role of its culture. ${ }^{37}$ Therefore, the organizational culture within the pesantren institution gives the spirit to the growth and development of the Islamic education institution, and becomes one of the pillars of competitive advantage for pesantren.

\section{B. Research Method and Objective}

This research uses a qualitative approach with a phenomenological type which focused on the dinamics of kiai's transformational leadership inpesantren in construct the organizational culture. This study aims to identify and analyze the transformational leadership style of KHMA when building the organizational culture of PNIA. Specifically, this study

Strategi Amerika Merusak Islam, dalamJurnal Kajian Islam AL-INSAN [Jakarta: Gema Insani Press], No. 2 Vol. 1, tahun 2005, h. 127.," t.t.

33 Sopiah, Perilaku Organisasional (Yogyakarta: Andi, 2008), 181.

34 Stephen P Robbins, Organizational Behavior.

35 Terrence E Deal dan Allan A Kennedy, Corporate Culture: The Rites and Rituals of Corporate Life. (Massachusens: Addison-Wesley, 1982).

36 Tobroni, The Spiritual Leadership: Pengefektifan Organisasi Noble Industry Melalui Prinsip-Prinsip Spiritual Etis, 115.

37 John P Kotter dan James L Heskett, Corporate Culture and Performance. (New York: The Free Press, 1992). 
focused on four factors of leading transformational leadership known as 4I; idealized influence, inspirational motivation, intellectual motivation, and individual consideration. Through these four factors, this research sees and maps the transformational leadership style as one of the effective and humanist leadership styles to build organizational culture in pesantren.

\section{Trnasformational Leadership}

Transformational leadership is a leadership style that is able to transform organizations to deal with dynamic change. Therefore, this leadership is said to be "a leadership perspective that explains how leaders change the team or organization by creating, communicating, and modeling a vision for the organization or work unit, and inspiring employees to strive for that vision". ${ }^{38}$ This leadership style empowers their followers and encourages them to "do more than they originally expected to do. Transformational leaders motivate followers to perform at higher levels, to exert greater effort, and to show more commitment". 39

As the result, transformational leader can have a strong influence on the strategic planning of pesantren, by setting the direction of organizational goals such as pesantren institutions. Abstract-latent issues can be translated into programs that are concrete-manifest. That is, through this leadership style, a leader is able to convey vision for the future and translate to the organizational structure. The kiai in this position has a transformative potential, as Steenbrink points out, the kiai's function in education is not limited to transference and interpretation of the source of Islam, the kiai also mediates into the divine realm. ${ }^{40}$ The kiai's role affects not only the dynamics of pesantren, but also the holistic community institution. ${ }^{41}$

Transformational leadership is a leadership process that between leaders and subordinates strives to achieve high level of morality and motivation. This leader tries to build awareness of his subordinates by setting for great ideals and high morality such as glory, togetherness and humanity.Transformational leadership is practiced when leader intellectually stimulates the subordinates, excites, arouses and inspires them to perform beyond their expectations. By providing a new vision, the transformational leader

38 Uhar Suharsaputra, Administrasi Pendidikan. Bandung: Refika Aditama, 2010, 124.

39 Michael Amstrong, Armstrong's Handbook of Management and Leadership: a Guide to Managing for Results. (London: Kogan Page, 2009).

40 Karel A Steenbrink, Pesantren, Madrasah, Sekolah: Pendidikan Islam dalam Kurun Modern (Jakarta: LP3ES, 1974), 146.

${ }^{41}$ Kuntowijoyo, Paradigma Islam: Interpretasi untuk Aksi (Bandung: Mizan, 1998), 257. 
transform the followers into people who want to self-actualize. Leader by inspiration have won wars by voluntarily demanding highest sacrifices of soldiers in the battlefields. History is replete of various examples of valour and sacrifices. Transformational leadership is beyond the charismatic leadership. ${ }^{42}$

The question that arises in this context is how a leadership style is said to be transformative leadership. Some leadership experts such as Nahavandi identified three factors, namely: charisma and inspiration, intellectual stimulation, and individual consideration..$^{43}$ Luthans $^{44}$ and Ladkin ${ }^{45}$ state that there are at least four factors, including: charisma, inspiration, intellectual stimulation, and individualized consideration. Bass \& Riggio identify four factors for declaring a person to apply a transformational leadership style through the Multifactor Leadership Questionnaire (MLQ): idealized influence, inspirational motivation, intellectual motivation, and individual consideration. 46

This study underpinned the views of Bass \& Riggio in identifying transformational leadership styles. The development of these leadership factors in the pesantren environment can be described as follows: first, idealized influence-charisma as a behavior of transformational leader of kiai in giving insight and awareness of vision and mission of pesantren, building and raising pride of pesantren civitas to the existence of pesantren institute, as well as cultivate an attitude of respect and trust in the pesantren community towards their own pesantren institution; Secondly, inspirational motivation is the kiai's behavior in spurring high expectations through the utilization of institutional symbols of pesantren to focus efforts and communicate the objectives to be achieved by pesantren with an effortless medium; Third, intellectual stimulation is a form of kiai's behavior to improve intelligence, rationality, and systematical problem solving, organized and effective integrated in pesantren civitas; Fourth, individualized consideration that is the transformational leadership behavior of kiai who continuously gives attention, guidance, creates space and trains pesantren civitas specifically and personally.

42 V.G Kondalkar, Organizational Behavior (New Delhi: New Age International Limited, Publishers, 2007), 242.

${ }^{43}$ Afsaneh Nahavandi, The Art and Science of Leadership., 186-87.

${ }^{44}$ Fred Luthans, Organizational Behavior: An Evidance-Based Approach (New York: McGraw-Hill, 2011), 430.

${ }^{45}$ Donna Ladkin, Rethinking Leadership: A New Look at Old Leadership Question (The United States of America: Edward Elgar Publishing, Inc., 2010), 4.

46 Bernard M Bass dan Ronald E Riggio, Transformational Leadership (New Jersey: Lawrence Erlbaum Associates, Inc., 2006), 20-21. 
Based on these transformational leadership factors, KHMA leadership in PNIA has succeeded in developing pesantren institution through strong pesantren culture. His leadership style projects the behavior of a leader who seeks to develop an ongoing system by proposing new values, norms, and beliefs that arise from Islamic doctrine. The development continues to move to transform the institutional system of pesantren that encourages the development of pesantren towards modern pesantren. This is in line with Zwell's view when identifying organizational success, he found that the basis for organizational success is leadership competence, worker competence, and organizational culture that strengthens and maximizes competence. ${ }^{47}$

\section{Organizational Culture}

Culture within social context is the whole understanding which includes knowledge, beliefs, arts, morals, laws, customs, and other skills and habits acquired by learning as members of a society. ${ }^{48}$ Within the scope of the organization, culture is a tool of values system, beliefs, assumptions, or long-standing norms, agreed and followed by members of a community as a code of conduct and organizational problem solving reference. 49 Nahavandi provides limits that culture is composed of common values built into a certain group. It is a set of norms, customs, values, and assumptions that guide the behavior of a particular group of people. ${ }^{50} \mathrm{In}$ harmony with these limits, Greenberg \& Barton define culture as a cognitive framework that contains the attitudes, values, behavior norms, and expectations that members of the organization have. 51

From these limitations, organizational culture can guide the behavior of members to fit the organization's role of game. Through organizational culture, dynamics of life and characteristics of its members can be understood. It is a common way to understand life and membership in organizations that bind members together and influence what they think about themselves and their work. ${ }^{52}$ When this understanding is drawn to

${ }^{47}$ Michael Zwell, Creating a Culture of Competence. (New York: John Wiley \& Sons, Inc., 2000), 9.

48 Norman Goodman, Society Today (United State of America: Gulf \& Western Corporation, 1978), 78.

${ }^{49}$ Edy Sutrisno, Budaya Organisasi (Jakarta: Kencana, 2010), 2.

50 Afsaneh Nahavandi, The Art and Science of Leadership., 34.

${ }^{51}$ Jerald Greenberg dan Robert A Barton, Behavior in Organizational (New Jersey: Prentice-Hall International, Inc., 2003), 515.

52 John A Wagner . dan John R Hollenbeck, Organizational Behavior: Securing Competitive Advantage. New York: Routledge., 2010, 283. 
the sphere of pesantren, it can be said that pesantren culture is a tool of the values system, beliefs, assumptions, or shared norms built in the pesantren environment to guide behavior of pesantren civitas. With organizational culture, the pesantren community will be bound by a commonly agreed "normative rules".53

Interestingly, organizational culture, as Schein observed, was formed and built by the founders of the organization. 54 Pesantren values are transmitted through lectures from kiai to his pupils. Since there is hardly any sphere of life untouched by the application of the recitation and kiai teaching, starting from the purification rituals means of performing worship up to the procedural provisions of the trade permitted by religion. Therefore, the pearching of the kiai to the pupils is equal to a process of establishing a complete set of values by means of its own assessment and orientation. The values (mores) created in the form of a series of daily deeds are then known as "the way of life of santri (pupils)". 55 The way of life of the santri in pesantren compared with the outside life of pesantren reading the wider community- has a significant difference. Therefore, pesantren by Wahid is said to be a "sub-culture".

Similar to organizational culture in profit and non profit institutions, pesantren culture has several main attributes. These attributes include: a). Values, namely shared beliefs and philosophy of its members; b). Organizational heroes or exemplars, which are members of the organization that have the best personalities and have strong values about organizational culture; c). The ritual, which is a symbolic ceremony to celebrate and strengthen the interpretation of organizational values; and d). Cultural communication network, that is the desired interaction channel to introduce members to organizational culture. ${ }^{56}$ Armstrong maps four major attributes, namely values, norms, artifacts, and management styles. ${ }^{57}$

Schein classifies attributes in three layers, a). The first layer includes artifacts and creations that seem real but often can not be interpreted; $b$ ). The second layer has values that are important to people. Values are

53 Nurul Mahmudah, "Pemberdayaan Pada Anak-Anak Gand Dolly di SMA Artantika Surabaya dengan Metode Asset Bassed Community Develpoment" 1 (2018): 13.

${ }^{54}$ Edgar H Schein, Organizational Culture and Leadership (San Fransisco: JosseyBass, 2010), 231.

${ }^{55}$ Abdurrahman Wahid, Menggerakkan Tradisi (Yogyakarta: LKiS, 2010), 7.

${ }^{56}$ Hendyat Soetopo, Perilaku Organisasi: Teori dan Praktek di Bidang Pendidikan (Bandung: Remaja Rosdakarya, 2010), 124.

57 Michael Amstrong, Armstrong's Handbook of Management and Leadership: a Guide to Managing for Results., 141-43. 
consciousness, affective desire, or desire; and c). The third layer is a basic assumption created by people to guide their behavior. Included in this layer are assumptions that tell the individual how to be perceived, thoughtful, and sympatic about work, performance goals, human relationships, and peer performance. ${ }^{58}$ Unlike the previous opinions, Kotter \& Hassket divide attributes on two levels: a). Unseen shared values, beliefs and important goals shared by groups that will shape group behavior and often persist and are difficult to change; and b). Explicit values of group behavior, the prevalent or pervasive way of acting found in a group and persisting because group members behave in this way and teach new members, but the later is easier to change. ${ }^{59}$

Based on the above mentioned expert classifications, the researcher follows the classification pattern developed by Edgar H. Schein. The pattern disentangles simplistic attribution by grouping between manifest and latent; physical and value (abstract aspect). Leaders -read kiai-can easily determine the direction of construction that they want to grow in their institutions. The range can be interpreted as an option for leaders to parse the growth of organizational culture.

Therefore, in the context of pesantren, the classification of pesantren culture needs to be seen critically by the kiai in order to open dialogical space with users and stakeholders of pesantren. The classification needs to be used as the main study for the socialization process of pesantren, since it is undeniable that the organizational culture has a very urgent role to the success of the organization including pesantren for several reasons, such as: first, to give members their organizational identity; second, to facilitate collective commitment; third, to improve the stability of social systems to reflect that the work environment is perceived positively and reinforced, conflict and change can be managed effectively; and fourth, to shape behavior by helping members to be aware of their surroundings. ${ }^{60}$

From several reasons, it can be concluded that the function of organizational culture in pesantren lies in the strength of its functionality. Strong organizational culture becomes a powerful tool to guide pesantren civitas behaviors help them do job better. On the other hand, it can reveal the polarity of the pesantren when facing internal and external challenges. All these implications will lead to improving the performance of pesantren

${ }^{58}$ Edgar H Schein, Organizational Culture and Leadership.

${ }^{59}$ John P Kotter dan James L Heskett, Corporate Culture and Performance., 5.

${ }^{60}$ Kreitner, Robert, \& Kinicki, Angelo. 2001. Organizational Behavior. New York: McGraw-Hill., 73. 
to realize the vision and mission of the institution. As Kotter \& Heskett's (1992:9) research states, an organization that emphasizes culture can increase its income by $682 \%$ compared to non-culture organizations, which can only increase its income by $166 \%$ within 11 years. ${ }^{61}$ In the view of Marno \& Supriyatno, the culture of educational organizations has a real impact on the achievement of educational goals; or even to the success and failure of educational organizations. ${ }^{62}$

\section{Kiai Transformational Leadership and Pesantren Organizational Culture}

Building PNIA culture, as performed by KHMA, is a conscious and planned effort arising from his ideality. The main objective is improving the performance of pesantren civitas including the aspect of strengthening the dynamics of institutional pesantren. It is unusual if its leadership style tends to integrate between intuition and sensitivity, creative opinion and strength, and perseverance to design a blend of educational strategy and pesantren culture. Factually, positive behaviors of transformational leadership have strong implications for institutional governance; 63 as suggested by Aydogdu \& Asikgil, ${ }^{64}$ Howard, ${ }^{65}$ Alajaili \& Hanley, ${ }^{66}$ or Sirin, et. al., ${ }^{67}$ which conclude the relationship between transformational leadership and organizational culture that is seen as the key to increasing commitment, productivity, and profitability as well as organizational effectiveness.

Therefore, the kiai among their followers in pesantren, have high awareness of their position as central and role models. In PNIA, the

61 John P Kotter dan James L Heskett, Corporate Culture and Performance., 9.

62 Marno dan Triyo Supriyatno, Manajemen dan Kepemimpinan Pendidikan Islam (Bandung: Refika Aditama, 2008), 141.

63 Sri Rahmi, Kepemimpinan Transformasional dan Budaya Organisasi: Ilustrasi di Bidang Pendidikan (Jakarta: Mitra Wacana Media, 2014), 139.

64 Sinem Aydogdu dan Baris Asikgil, "The Effect of Transformational Leadership Behavior on Organizational Culture: An Application In Pharmaceutical Industry," 20111 (4) (65-73.): 65-73.

65 Mildered Patricia Howard, . . A Study of The Relationship Between Transformational Leadership and Organizational Culture, (Dissertation) (Michigan: Western Michigan University, 2004).

66 Tareq Abu Fares Alajaili dan David Hanley, "Role ofTransformational Leadership and the Impact of Organizational Culture in the Petroleum Sector of Libya" 20 (9) (2018): 77-87.

67 Yeliz Erath Sirin et. al., "Transformational-Transactional Leadership and Organizational Cynicism Perception: Physical Education and Sport Teachers Sample" 6 (9) (2018): 2008=2018. 
establishment of pesantren culture is built not only from KHMA initiation. The magnitude of its influence determines the methods, beliefs, behaviors, and actions undertaken by pesantren civitas. In one study, Soebahar points out the role of the kiai in creating democratic and inclusive attitudes to respond to gender issues and provide the pesantren he leads as a platform for conversation and the movement of women's empowerment. Until now, the thinking and attitude of kiai's moderation can inspire the birth of gender relation in pesantren so that PNIA is considered as Gender Pesantren in East Java. ${ }^{6}$

Interestingly, KHMA moderate and progressive attitude in addressing the normative texts of Islam -al-Qur'an and al-Hadith is very clear. He is courageous to reinterpret the text to suit the context of modern life. Classical texts such as the Book of 'Uqud al-Lujjain which is widely used as the legitimacy of gender imbalances are strictly forbidden by the kiai unless they are interpreted in the spirit of equality of men and women. This formula indicates the innovations initiated by the kiai and reflected by the integration of individual interests of the pesantren civitas with their institution.

Gradually, the construction of ideas and attitudes of the kiai are incarnated in the structure of institution pesantren value. This value is regarded as a measure, containing the truth about the beliefs and behaviors of the pesantren civitas, so that this value is the most adhered to and used in any decision-making event. Similarly, the implementation of pesantren educational activities cannot be separated from these values as rules and guidelines described in each behavior.

Outside the pesantren environment, the value is a form of factor, driving the behavior of pesantren civitas and encourage the kiai's superiority compared with other pesantren civitas. One of the most prominent behaviors is the attitude of tolerance (tasamuh), that is by respecting the differences and respecting other people or groups who have different life principles. This value arises based on the interpretation of the kiai on the text of the Qur'an surah Thaaha verse 44 about the dialogue of prophets Moses, prophets Aaron and Pharaoh. Other attitudes are balance (tawazun) and fairness ( $i^{\prime}$ tidal) derived from the pesantren ideology based on the practice and tradition of Nahdlatul Ulama' (NU) religious organization.

68 Abd. Halim Soebahar, "Pesantren Gender: Rekonstruksi Tiga Pesantren di Jawa, dalam Dialog No. 58 Tahun 2004.," t.t., 54; Umiarso, Kepemimpinan Transformasional Profetik: Kajian Pradigmatik Ontos Integralistik di Lembaga Pendidikan Islam (Jakarta: Prenadamedia Group., 2018), 168. 
Their commitment to the values has driven the attention of the pesantren civitas to be aimed entirely at the substance of education of pesantren. At this time, the kiai provides inspiration and motivates pesantren civitas to see wider and more varied opportunities. He invites them to achieve high standards of success by creating spaces of creation. It is not unusual in the PNIA if there is a community of female pupils playing soccer or volley ball. However, this freedom is not without limits, this freedom is limited by the Islamic ethical values raised from the moderation of understanding of classical texts (classical holy books).

The pattern encourages the kiai to form mentality and morality of a strong pesantren member. The internalization of the normative values of Islamic character is further strengthened through the process of doctrination and habituation. Their space of creation is framed by Islamic culture derived from the Qur'an such as the value of monotheism (QS. alIkhlas: 1-4), ethics or akhlaq al-karimah (QS. al-Baqarah: 177), the value of honesty (QS. at-Taubah: 119), responsibility (QS. al-Mudatstsir: 38), or respecting the laws and regulations (QS. an-Nisa': 59). Kiai, in the process of developing the pesantren culture, does so as it is planned, directed, and focused on the goal. The pesantren community is directed to understand, live and practice the values through various types of formal education activities (MTs/SMP, MA/SMA/SMK) for the development of integrated pesantren culture. On the other hand, the efforts to build a pesantren culture are integrated with "normative clock" of formal education that does not interfere with their substantive set schedule of Teaching and Learning Activities. Through the process of integration, educational personnel have responsibility in the form of teaching (worldly domains) and guidance (ukhrowi domain). He is not only required to carry out academic obligations (teaching), but also required to train, guide and pray for learners.

Observing the dynamic initiation of the pesantren's culture, kiai has an important role as layers of knowledge of how to behave in pesantren. All the behaviors of pesantren civitas refer to the system of ideas, the socialized behavior, and the results of behavior that will or has been felt. The researcher sees the systematic idea of pesantren culture raised by kiai from the social construction of mind and the kiai's construction of knowledge. Meanwhile, the behavior in which there is a communicating system is articulated in the form of a patron-client system and is dialogical. The result of such behavior is based on social construction of pesantren's science system which is commonly derived from classical texts (yellow book).

As the kiai occupies a central position, he positions himself as a role model (uswah hasanah) who does not rely on his own personal charisma. Since the kiai's attitude that upholds the pluralism in the environment of 
pesantren, he invites pesantren civitas to appreciate the differences in society. In fact he distributes his authority to his young fellows as a series of pesantren empowerment and encourages them to become leaders. In this context, however, the kiai does not impose his will to be done by the pesantren civitas; firstly, he understands their potential, ability and emotional stability. The sensitivity of the kiai is said to be an intellectual emphaty. 69

Upon reaching the increasing of potential of pesantren civitas, the kiai continues to make some betterment and improve other aspects. The potentials and competencies of the pesantren are opened for distribution, so that all of them can increase their potential. Through such pattern, he creates harmony and ultimately encourages pesantren civitas to develop selfdiscipline as well as to realize the goal of education PNIA. KHMA underlies the foundation with normative value of the Qur'an, QS. an-Nisa verse 32 which describes the necessity of a just attitude. Theoretically, Barnes in Uha has identified ten Kaizen leadership principles, ${ }^{70}$ similar to the kiai's.

Kiai has a sophisticated ideal of the pesantren that he built; the values and beliefs are adapted to Islamic ethics. However, he is elastic in responding to the condition of the pesantren environment in order to continuously make improvements and changes. Consequently, in the process of building the pesantren culture there is thesis and antithesis to achieve conformity. Interestingly, after reaching this conformity the kiai does not stop but he performs innovative creations. He is restless within the sphere of the status quo and invites the pesantren civitas to continue to transform the system in a better direction.

Those processes are forms of actualization of the Qur'an surah AlMaidah verse 16. The concept of "min al-dhulumat ila al-nur" is interpreted as a transformative process from low point to high point. This process can also be interpreted as a metamorphosis of pesantren institution to modern pesantren culture with various prestigious Islamic educational ornaments. Kiai has designed the transformation of the pesantren institution's culture through the internalization of values and beliefs that gave rise to a sense of pride in pesantren. One example is the white-and-white uniform (white sarong, white koko shirt, and white cap) capable of generating a sense of

${ }^{69}$ Sri Rahmi, Kepemimpinan Transformasional dan Budaya Organisasi: Ilustrasi di Bidang Pendidikan, 183.

70 Ismail Nawawi Uha, Budaya Organisasi, Kepemimpinan \& Kinerja: Proses Terbentuk, Tumbuh Kembang, Dinamika, dan Kinerja Organisasi. (Jakarta: Kencana, 2013), 158-60. 
pride for pupils and at the same time a self-control tool to avoid bad behavior. Every individual who is on a different level from badal, santri, boarding school administrator or ustadz tends to give the same understanding to it.

Although sometimes there is disagreement from internal circles and from community around the pesantren itself, the kiai builds pesantren culture evolutively through critical reading of skill, competence, and environment potential. In addition, the kiai combines the conventional pesantren management that tends to do preaching with the philosophical value of users or more modern stakeholders. The advantage is that the kiai can build new habits within the pesantren environment that will unconsciously emerge as a culture.

On the one hand, the culture of the pesantren that was formed evolutively has been able to be more adaptive to face the challenges of the times. One example is the birth of vocational education institutions such as vocational schools in the pesantren environment. This cannot be separated from the demands of the current era that require graduates to have skills in the field of science but also strong in religious knowledge. Along with the existence of this adaptive dynamics, pesantren further strengthens integrative education system (non-dichotomic) between science of religion and general science. Hence, the term "religious scientist" or "scientific religious scholars" has been familiarly heard.

It means, PNIA that has a strong pesantren culture, has emerged from the self-ideals of the kiai. The ideality born of his religiousity followed by the attempt to interpret and translate the Islamic doctrine formulated in the Qur'an and al-Hadith. This process is an attempt of the kiai to contextualize Islamic doctrine in the life of pesantren. This is fair to the kiai, because he has a strong religious tradition of religion and is sustained by a religious family background. It is the result of thinking, because it is a substance that spreads through consciousness and thought manifests itself as the reason of a tradition. In contrast the stretch of modernization and globalization tends to bring destructive attitudes and exclusion of the religious sense of society. These can be identified in the transnational movement of radicalism in the name of religion, the number of fights between students, or free sex. This mapping indicates that pesantren culture is the "result of construction" of kiai who is willing to open the dialogue room with other potentials.

\section{Transformational Leadership Based on Religious Attitude}

There is a wide opportunity enabling the management of pesantren to be considered as a professional Islamic educational institution with a high level of effectiveness. This management is able to produce human resource 
outcomes ready to compete. At this time, pesantren is not always in the path of religious preaching, but it has shifted to a more complex dimension. This situation disputes Qomar's view that traditional pesantrens are mostly managed traditionally. ${ }^{71}$ The "opportunity" has embodied a mature pesantren management's effort by generating effective learning, open organizational adaptation, and having a strong pesantren culture. Pesantren cannot be separated from the ability of transculturalism to the changes that occur. ${ }^{72}$ That is, he not only assimilates and acculturates the culture, but also projects the culture for the future (worldly and ukhrawi).

Therefore, Ziemek states that in organizing a pesantren, the kiai focuses not only for economic purposes but for the sake of religion..$^{73}$ In PNIA, KHMA leadership has designed the management of pesantren with normative achievements. When designing the standards for achieving educational success, he applies a double standard. The first standard is designed for the attainment of worldly (quantitative) successes such as the mastery of religious and general science, and the second lies in the practice of science for post-life (ukhrawi) (qualitative) life.

The kiai's leadership style is a form of his ability to nurture, guide and manage the pesantren through others -read the pesantren civitas- in order to transform the pesantren optimally, especially to the human resources to achieve the worldly and ukhrawi goals. Gradually, the leadership style of this kiai is able to bring changes to institutional pesantren through the development of effective managerial governance of education. Hodaifah's research results indicate that this pesantren is able to establish itself in the typology of moderate pesantren that teaches the tolerance, moderate books in tolerant environment of Aswaja, that follows al-muhafadzah ala al-qadim alshalih (running old good deeds), and the rule of al-akhdah bi al-jadid al-aslah (absorbing better perceived new deeds). ${ }^{74}$

The kiai leadership behavior, in addition to building a strong pesantren culture, impacts on the creation of an effective and efficient pesantren behavioral system. The kiai seeks to cultivate socio-cultural desires such as self esteem or self actualization, even the improving needs of the religious level (metaphysical, absolute). It is common that the devotion and

71 Mujamil Qomar, Manajemen Pendidikan Islam: Strategi Baru Pengelolaan Lembaga Pendidikan Islam (Jakarta: Erlangga, 2007), 59.

${ }^{72}$ Zulfikri, "Modernisasi Pesantren: Pergeseran Tradisi dan Pudarnya Kyai" 3, no. (2) (2005): 75-94.

73 Manfred Ziemek, 1986. Pesantren dalam Perubahan Sosial trans;Butche B. Soendjojo (Jakarta: P3M, t.t.), 9.

74 Hodaifah, Urgensi Moderatisme dalam Pendidikan Islam (Jember: Pustaka Radja, 2014), 202. 
commitment of pesantren civitas to pesantren and the kiai is very powerful in order to receive barakah (holiness, virtue as an inherent spiritual force). Lukens-Bull admit that the pesantren community generally wants to be able to absorb (receive)..$^{75}$ Moreover, according to Tan, the kiai is set as a source of barakah for his followers. ${ }^{76}$

This leader's behavior is the characteristic and uniqueness of kiai's transformational leader. He pays attention to the needs of the pesantren's civitas to influence and "master" it, so that they were able to focus their performance on the goal of pesantren. He not only pays attention to the needs of pesantren civitas personally, but is collective by helping them to grow and develop into a religious leader. He appears as a leader who pays great attention to the humanist side of pesantren through the attitudes of nurturing, educating, guiding, and directing. These attitudes are developed on the principle of amr ma'ruf nahi munkar that arises from the religious awareness of the kiai; This is what is commonly referred to as tawheed ethics. Therefore, the leadership behavior of the kiai will not be separated from the normative values of the religion it embraces. As mandated in the al-Qur'an surah Ali Imran verse 118, a leader has to keep walking on a line; the line that has been determined by God.

Based on the religious awareness motive, the kiai's leadership behavior in managing pesantren is strongly adhering to God's line (al-Qur'an and alHadist). The motive will influence, motivate, and mobilize pesantren civitas to be guided by religious values. The kiai and the pesantren community, while raising themselves to higher levels of morality and motivation (such as freedom, justice and humanity), are guided by religious values, not based on mere emotions (such as greed, social jealousy or hatred). This behavior can be referred to as a leadership style based on religious awareness. ${ }^{77}$

Kiai, in managing pesantren, uses the heart and mind as the main aspects. The heart -read intuition- is the medium of building the values of

75 Ronald Lukens-Bull, A Peaceful Jihad: Negotiating Identity and Modernity in Muslim Java (New York: Palgrave MacMillan, 2005), 1.

${ }^{76}$ Charlene Tan, Islamic Education and Indoctrination: The Case in Indonesia. (London: Routledge, 2011), 56; Arif Junaidi, “Pergeseran Mitologi Pesantren di Era Modern" 19 (2) (2011): 1.

77 Thayib, "Spiritual Leadership, Kepuasan Kerja, dan Prestasi Kerja" 16 (2) (2013): 351-82; Abdul Basit, "Habitual Action dalam Kepemimpinan Spiritual: Studi Kepemimpinan Spiritual di Stain Purwokerto" 7 (1) (2013): 1-19; Phuong V Nguyen et. al., "The Role of Leader's Spiritual Leadership on Organisation Outcomes" 23 (2) (2018): 45-68; Peter Rigii Gaitho, "Influence of Religion on Leadership Styles and Leadership Roles" 7 (1) (2019): 8-11. 
purity in leading an organization, so that the leadership process is colored by obedience without coercion, compassion and sincerity that does not expect any "reward" other than God's gifts and mercy. The mind is used as a medium to think about the dynamics of pesantren institution to create innovations and creations that are framed by religious values. Even the Qur'an itself is placed as a paradigm that builds organizational knowledge (management) of pesantren. The goal is that all pesantren members including the kiai himself have the "wisdom" to form behavior that is in line with the system of its religion. Thus, in addition to providing an axiological picture, the Qur'an paradigm can also serve to provide an epistemological insight into management and leadership.

Similarly, within the operation framework of the interpretive methodology, hearts and minds are the main medium for understanding the Qur'an, the activities of the Prophet (as-Sunnah) and the socio-historical setting as well as the dynamics of organizing Islamic education. This interpretation is conducted to reform the management of intact boarding school, coherent and oriented in the present. That is, the interpretation of al-Qur'an and al-Hadist attempted to be able to reconstruct the management of pesantren in accordance with the breath of modernity. Therefore, the kiai first formulates the world view of al-Qur'an and alHadist such as ontology, epistemological, and axiological aspects of functional management. From this framework, many pesantren cultural values have emerged and formed the personality of PNIA.

Therefore, it is appropriate if the kiai leadership steps often bring up the vision and educational innovation that inspire the pesantren community. Fundamentally, these behaviors underline the transformational leadership style; as Baharudin \& Umiarso urge, that every subordinate will follow the leader of the organization; a leader who can give them inspiration with a clear vision and with good means and energy to achieve a great goal. ${ }^{78}$ Vision becomes the normative reference of the pesantren organization movement and is a great hope for the future. Kiai often conveys something "preached" by raising the view and hope of the future that the pesantren wants to achieve by combining all the strengths, abilities and potential of the civitas.

However, the kiai does not necessarily build great expectations with an autonomous formulation of itself. He, together with other civitas, brings together a commitment to build and realize the great hope. One tradition and a cultural value in achieving a shared commitment are through "syuro". In this forum there is a dialectical process to reach a "consensus" that is not

78 Baharuddin dan Umiarso, Kepemimpinan Pendidikan Islam: Antara Teori dan Praktek. (Yogyakarta: Ar-Ruzz Media, 2012), 222. 
contrary to religious values. This deliberation forum serves to accommodate all the aspirations and inspiration of learners and combine thoughts together until the most thoughtful form of thought emerges. Interestingly, the dynamics of this discussion forum emerged in pesantren is because of the religious motives of the kiai. Amanah is summed up in alQur'an Surah al-Syuura verse 38, which is as a manifestation of kiai's religiousness in pesantren management actualized in the style of his leadership.

If it is seen from the Qur'anic verse (QS. al-Syuura: 38) it has been mentioned that believers have the characteristics of: "welcoming" every call of God, establishing prayers, and deliberating their affairs. In the concept of prophetic leadership, as illustrated by Hendrawan, discussion is an integral part of the problem of amr ma' ruf nahi munkar. ${ }^{79}$ Therefore, the kiai puts the deliberation in a very strategic position to decide and run various educational programs as well as to build the culture of PNIA. KHMA does not actualize ideas without any dialogue process with pesantren society.

Based on the existing pesantren phenomenon, deliberation becomes an essential part to bring about change in PNIA. The fundamental style of the kiai's transformational leadership is the democratic process of reaching "consensus" in the guidance of religious values (al-Qur'an and al-Hadith). Changes that occur in pesantren through kiai innovations cannot be separated from the main basis of al-Qur'an and al-Hadist as ideology and foothold thinking. The goal is to put the values of management education in accordance with the ideals and vision of Islam on humanitarian social transformation.

All the cultural buildings, ranging from philosophical frameworks to practical values are bound by the basis of religious social transformation. It serves to explain the real condition of pesantren today and at the same time provide insight about the change and transformation of pesantren, especially in following the changing of modern era. Consequently, clusters of institutional management are derived from an ideology with an interest in transformation; moving from negative to positive. This transformative spirit is what the kiai continuously holds for maintaining and developing pesantren, although it still retains the old values that are still relevant to the modern education system. This is to sum up a principle of al-mukhafadah alqodim al-shaleh wa al-akhduh bi al-jadid al-ashlah.

Transformative spirit encourages Kiai to create innovative space for pesantren society in improving performance. Occasionally, he provides

79 Saherya Hendrawan, Spiritual Management: From Personal Enlightement Towards God Corporate Governance (Bandung: Mizan, 2009), 181. 
rewards to motivate them. He believes that one form of effective motivation is through reward system, based on the accomplishment of his pupils with his pupils. Kiai is certain; this method will clearly encourage pupils to achieve maximum work performance. Therefore, the kiai gives various rewards in accordance with their achievements. The higher the achievement they reach, the greater the rewards they receive. This balance pattern is inspired by the principle of justice that was implemented in the prophet Daud era. God commanded the prophet to be a fair leader in deciding cases (QS. Shaad: 26).

In addition to the basis of "achievement" or the achievement of maximum performance; Kiai provides reward driven by feelings of love and affection. In one study it is said that in educational organizations the foundation of love and affection can increase their productivity performance. ${ }^{80}$ It occurs since this feeling is directly proportional to the recognition of the existence of humanity; in which the pesantren civitas feel much humanized by the kiai. Therefore, it is common when Miller \& Browning state that love is able to launch the path of leadership. ${ }^{81}$ Through this love and compassion, the kiai encourages the pesantren community to reach the present (world living) and the future (ukhrawi) success.

Therefore, this transformational leadership style not only brings about institutional change and educational systems, but also provides a "wisdom" that relies on virtues and religious values. Such a leadership pattern can be said to be religious-based transformational leadership. He not only represents the values of transformational leaders that focus more on the achievement of the objectives and the realization of the vision through the moral and quality performance of the civitas (horizontal aspect in constructing khalifah fil al-ard), but also focuses on the achievement of Allah's pleasure (vertical aspect in constructing abdullah). These two foci are what the researcher termed the concept of leadership, because it refers to the two constructs.

To measure the religious-based transformational leadership style, there are two dimensions. The conventional standard dimension of Multifactor Leadership Questionnaire (MLQ) that has been formulated by Bass, and ethical-religious dimensions such as behavior, which encourages subordinates to be more aware of the importance of the process of achieving results and the results of the enterprise itself (worldly and

${ }^{80}$ Bahar Agus Setiawan dan Abd Muhith, Transformational Leadership: Ilustrasi di Bidang Organisasi Pendidikan, 75-78.

81 Ron Miller dan Sommer Browning, Cleopatra (New York: Chelsea House Publishers, 2010), 7. 
enduring aspects); encouraging subordinates to advance the interests of the organization rather than individual interests on the basis of socio-religious ethics; increasing the need for higher subordinates such as self-esteem, selfactualization and spirituality (worship to God); encouraging subordinates to cultivate the awareness of the divinity (tauhid), so that it helps to arise teo-antropocentric behavior. It is a behavior that brings grace to the organization based on the values of religiosity.

The implications of this theoretical framework are on conceptual leadership design. The theory that is believed to be so far in raising an effective leadership framework does not correlate with the values of religiosity. One of them states that effective leadership is:

"a model of leadership influenced by the theory of Transformational Leadership includes five main components necessary for a strong leader: Communicating Direction, Inspirational Motivation, Problem Resolution, Building the Team, and Trust. The core of this model is trust because this is the foundation of any effective leader". 82

From these five aspects, there needs to be a "revamping" or reconstruction that is by incorporating eschatological-transcendental values (worship to and blessing from Allah). Thus, effective leadership is not only able to bring management of Islamic educational institutions on the order of effectiveness with the productivity improvement of educational institutions and customer satisfaction stakeholders, especially consumers, but also able to fulfill the desired pleasure to God so that the educational institutions civitas are capable of conducting ma' rifah to God.

\section{E. Closing}

Based on the writer's description it can be concluded that the kiai, in building the pesantren culture, does so with the conscious and planned effort that emerges from his idealism as a social-organizational and prophetic actor. In the process, he actualizes the transformational leadership style-through the dimensions of idealized influence, inspirational motivation, intellectual motivation, and individual consideration-based on religious values. It is this combination of values that continually reinforce institutional cultural building for its growth and positive development. Moreover, this combination can achieve the purpose and the realization of the vision of pesantren through the high moral and

82 Donna J Dennis dan Deborah Dennis Meola, Preparing For Leadership: What it Takes to Take the Lead (New York: Amacom, 2009), 5. 
performance of pesantren civitas (khalifah fil al-ard) and also for the sake of Allah's mercy (abdullah).

This religious-based transformational leadership style has positive implications for improving the performance and work attitude of pesantren civitas, including on the strengthening of institutional dynamics. This leadership style changes not only oriented to the achievement of the objectives, mission and vision of the pesantren, but also focused on the human resources aspect. Therefore, their professional attitude and performance are able to exceed institutional expectations[.]

\section{REFERENCES}

Abd. Halim Soebahar. "Pesantren Gender: Rekonstruksi Tiga Pesantren di Jawa, dalam Dialog No. 58 Tahun 2004.," t.t.

Abd Wahab, dan Umiarso. Kepemimpinan Pendidikan dan Kecerdasan Spiritual. Yogyakarta: Ar-Ruzz Media, 2011.

Abdul Basit. "Habitual Action dalam Kepemimpinan Spiritual: Studi Kepemimpinan Spiritual di Stain Purwokerto" 7 (1) (2013): 1-19.

Abdurrahman Wahid. Menggerakkan Tradisi. Yogyakarta: LKiS, 2010.

Achmad Patoni. Peran Kiai Pesantren dalam Partai Politik. Yogyakarta: Pustaka Pelajar, 2007.

Ali Anwar. Pembaruan Pendidikan di Pesantren Lirboyo Kediri. Yogyakarta: Pustaka Pelajar, 2011.

Bahar Agus Setiawan, dan Abd Muhith. Transformational Leadership: Ilustrasi di Bidang Organisasi Pendidikan. Jakarta: Rajawali Pers, 2013.

Baharuddin, dan Umiarso. Kepemimpinan Pendidikan Islam: Antara Teori dan Praktek. Yogyakarta: Ar-Ruzz Media, 2012.

Bernard M Bass, dan Ronald E Riggio. Transformational Leadership. New Jersey: Lawrence Erlbaum Associates, Inc., 2006.

Bianca J Smith, dan Mark Woodward(Edit.). . Gender and Power in Indonesian Islam: Leaders, Feminists, Sufis and Pesantren Selves. London: Routledge, 2014.

Biyati Ahwarumi, dan Tjiptohadi Sawarjuwono. "Enhancing Innovation

Roles of Pesantren Business Incubator in Pondok Pesantren Sunan Drajat" 1 (2) (2017): 71-82.

Tony Bush. Leadership and Management Development in Education. London: Sage Publishing, 2008.

Charlene Tan. Islamic Education and Indoctrination: The Case in Indonesia. London: Routledge, 2011. 
Abu Choir. "Manajemen Entrepreneurship Berbasis Pesantren dalam Pengembangan Sumber Pembiayaan Pendidikan: Studi Multikasus pada Pondok Pesantren Maslakul Huda Kajen Margoyoso, Pondok Pesantren al-Isti' anah Plagitan Pati, dan Pondok Pesantren Manbaul Huda Kembang Dukuhseti Kabupaten Pati Jawa Tengah." Universitas Islam Negeri Maulana Malik Ibrahim, 2016. Dissertation Summary.

Kerri Anne Crowne. "Investigating Antecedents of Transformational Leadership in Students" 12, no. (1) (2019): 80-94.

Terrence E Deal, dan Allan A Kennedy. Corporate Culture: The Rites and Rituals of Corporate Life. Massachusens: Addison-Wesley, 1982.

Donna J Dennis, dan Deborah Dennis Meola. Preparing For Leadership: What it Takes to Take the Lead. New York: Amacom, 2009.

Edgar H Schein. Organizational Culture and Leadership. San Fransisco: JosseyBass, 2010.

Edward Sallis. Total Quality Management in Education. London: Kogan Page, 2002.

Edy Sutrisno. Budaya Organisasi. Jakarta: Kencana, 2010.

Nur Efendi. Manajemen Perubahan di Pondok Pesantren: Konstruksi Teoritik dan Praktik Pengelolaan Perubahan sebagai Upaya Pewarisan Tradisi dan Menatap Tantangan Masa Depan. Yogyakarta: Teras, 2014.

Endang Turmudi. Perselingkuhan Kiai dan Kekuasaan. Yogyakarta: LKIS, 2003.

Saidin Ernas, dan Ferry Muhammadsyah. "Dampak Keterlibatan Pesantren dalam Politik: Studi Kasus Pesantren di Yogyakarta" 25 (2) (2010): 195224.

Peter Rigii Gaitho. "Influence of Religion on Leadership Styles and Leadership Roles" 7 (1) (2019): 8-11.

Gary F Bell. "Indonesia: The Challenges of Legal Diversity and Law Reform," in E. Ann Black, Gary F. Bell (eds.). Gary F. Bell. Law and Legal Institutions of Asia: Traditions, Adaptations and Innovations. New York: Cambridge University Press, 2011.

Norman Goodman. Society Today. United State of America: Gulf \& Western Corporation, 1978.

Jerald Greenberg, dan Robert A Barton. Behavior in Organizational. New Jersey: Prentice-Hall International, Inc., 2003.

Saherya Hendrawan. Spiritual Management: From Personal Enlightement Towards God Corporate Governance. Bandung: Mizan, 2009.

Hendyat Soetopo. Perilaku Organisasi: Teori dan Praktek di Bidang Pendidikan. Bandung: Remaja Rosdakarya, 2010.

Nurul Hidayah. Kepemimpinan Visioner Kepala Sekolah dalam Meningkatkan Mutu Pendidikan. Yogyakarta: Ar-Ruzz Media, 2016. 
Hodaifah. Urgensi Moderatisme dalam Pendidikan Islam. Jember: Pustaka Radja, 2014.

Mildered Patricia Howard. . . A Study of The Relationship Between Transformational Leadership and Organizational Culture, (Dissertation). Michigan: Western Michigan University, 2004.

Imam Suprayogo. Kyai dan Politik: Membaca Citra Politik Kyai. Malang: UINMalang Press, 2009.

Ismail Nawawi Uha. Budaya Organisasi, Kepemimpinan \& Kinerja: Proses Terbentuk, Tumbuh Kembang, Dinamika, dan Kinerja Organisasi. Jakarta: Kencana, 2013.

Jaap Scheerens (Edit.). School Leadership Effects Revisited: Review and MetaAnalysis of Empirical Studies. New York: Springer, 2012.

Jamal Lulail Yunus. Leadership Model: Konsep Dasar, Dimensi Kerja, dan Gaya Kepemimpinan. Malang: UIN Malang Press, 2009.

John A Wagner ., dan John R Hollenbeck. Organizational Behavior: Securing Competitive Advantage. New York: Routledge., 2010.

Arif Junaidi. “Pergeseran Mitologi Pesantren di Era Modern" 19 (2) (2011): 511-30.

Karel A Steenbrink. Pesantren, Madrasah, Sekolah: Pendidikan Islam dalam Kurun Modern. Jakarta: LP3ES, 1974.

Khozin. "Pola Interaksi Pesantren dengan Lingkungan Sosialnya dalam Perspektif Sosio-Historis" 1 (1) (2016): 71-90.

V.G Kondalkar. Organizational Behavior. New Delhi: New Age International Limited, Publishers, 2007.

John P Kotter, dan James L Heskett. Corporate Culture and Performance. New York: The Free Press, 1992.

Kuntowijoyo. Paradigma Islam: Interpretasi untuk Aksi. Bandung: Mizan, 1998.

Donna Ladkin,. Rethinking Leadership: A New Look at Old Leadership Question. The United States of America: Edward Elgar Publishing, Inc., 2010.

Lihat Zamakhsyari Dhofir, Tradisi Pesantren: Studi tentang Pandangan Hidup Kyai, (Jakarta: LP3ES, 1994); Kamaruzzaman Bustamam-Ahmad, Islam Historis: Dinamika Studi Islam di Indonesia, (Yogyakarta: Galang Press, 2002, ) hal.65-82., t.t.

Ronald Lukens-Bull. A Peaceful Jihad: Negotiating Identity and Modernity in Muslim Java. New York: Palgrave MacMillan, 2005.

Fred Luthans. Organizational Behavior: An Evidance-Based Approach. New York: McGraw-Hill, 2011.

Mahmudah, Nurul. "Pemberdayaan Pada Anak-Anak Gand Dolly di SMA Artantika Surabaya dengan Metode Asset Bassed Community Develpoment" 1 (2018): 13. 
“Majalah US News, dalam edisinya terbaru menurunkan laporan panjang tentang perang pemikiran yang sedang diluncurkan Amerika Srikat. Dalam artikel yang diutlis oleh David E. Kaplan, diungkapkan bahwa pada front yang tersembunyi dalam perang melawan terorisme, Amerika membelanjakan jutaan dolar untuk mengubah wajah Islam. 'in an unseen front in the war on terrorism, America is spending millions to Change the Very Face of Islam'. (Huaim Hidayat, Strategi Amerika Merusak Islam, dalamJurnal Kajian Islam AL-INSAN [Jakarta: Gema Insani Press], No. 2 Vol. 1, tahun 2005, h. 127.," t.t.

Manfred Ziemek. 1986. Pesantren dalam Perubahan Sosial trans;Butche B. Soendjojo. Jakarta: P3M, t.t.

Mardiyah. Kepemimpinan Kiai dalam Memelihara Budaya Organisasi. Yogyakarta: Aditya Media Publishing, 2012.

Marno, dan Triyo Supriyatno. Manajemen dan Kepemimpinan Pendidikan Islam. Bandung: Refika Aditama, 2008.

Mats Alvensson. Understanding Organizational Culture. London: Sage Publication, 2002.

Tatiana Melguizo, dan Hamish Coates. "The Value of Assessing Higher Education Student Learning Outcomes" 3 (3) (2017): 1-2.

Michael Amstrong. Armstrong's Handbook of Management and Leadership: a Guide to Managing for Results. London: Kogan Page, 2009.

Michael Baptiste. "No Teacher Left Behind: The Impact of Principal Leadership Style on Teacher Job Satisfaction and Student Success, in Journal of International Education and Leadership 9 (1) 2019, 1-11.," t.t.

Michael Zwell. Creating a Culture of Competence. New York: John Wiley \& Sons, Inc., 2000.

Ron Miller, dan Sommer Browning. Cleopatra. New York: Chelsea House Publishers, 2010.

Mujamil Qomar. Manajemen Pendidikan Islam: Strategi Baru Pengelolaan Lembaga Pendidikan Islam. Jakarta: Erlangga, 2007.

Farhat Munir, dan Muhammad Aboidullah. "Gender Differences in Transformational Leadership Behaviors of School Principals and Teachers' Academic Effectiveness," 2018. Bulletin of Education and Research.

Afsaneh Nahavandi. The Art and Science of Leadership. New Jersey: Prentice Hall, Inc., 2000.

Nasaruddin Umar. Rethinking Pesantren. Jakarta: Kompas Gramedia, 2014.

Naufal Ahmad Rijalul Alam. "Strengthening Leadership Culture: The Role of Kyai in Indonesia Pesantren" 13 (1), no. 2018 (t.t.): 5-17.

Phuong V Nguyen et. al. "The Role of Leader's Spiritual Leadership on Organisation Outcomes" 23 (2) (2018): 45-68. 
Nur Khusniyah Indrawati. "Management by Inspiration: Implementation of Transformational Leadership on Business at Pondok Pesantren Sunan Drajat" 115 (2014): 79-90.

Nurul Azizah. Artikulasi Politik Santri: Dari Kyai Menjadi Bupati. Yogyakarta: Pustaka Pelajar, 2013.

Raihani. Kepemimpinan Sekolah Transformatif. Yogyakarta: LKiS, 2010.

Ronald S Barth. Improving School from Within. San Francisco: Jossey-Bass., 1990.

Shaun Tyson, dan Tony Jackson. The Essence of Organizational Behaviour: Perilaku Organisasi, Peterj.: Deddy Jacobus \& Dwi Prabantini. Yogyakarta: Andi, 2009.

Sinem Aydogdu, dan Baris Asikgil. "The Effect of Transformational Leadership Behavior on Organizational Culture: An Application In Pharmaceutical Industry." 20111 (4) (65-73.): 65-73.

Siswanto, et. al. "Entrepreneurial Motivation in Pondok Pesantren" 3 (2) 2013 (t.t.): 42-54.

Sopiah. Perilaku Organisasional. Yogyakarta: Andi, 2008.

Sri Rahmi. Kepemimpinan Transformasional dan Budaya Organisasi: Ilustrasi di Bidang Pendidikan. Jakarta: Mitra Wacana Media, 2014.

Stephen P Robbins. Organizational Behavior. New Jersey: Prentice Hall, 2001. Stephen P Robbins, dan Mary Coulter. Management. New Jersey: Prentice Hall., 2012.

Sukamto. Kepemimpinan Kiai dalam Pesantren. Jakarta: LP3ES, 1999.

Sukarno. Budaya Politik Pesanten Perspektif Interaksionisme Simbolik. Yogyakarta: Interpena, 2012.

Tareq Abu Fares Alajaili, dan David Hanley. "Role ofTransformational Leadership and the Impact of Organizational Culture in the Petroleum Sector of Libya" 20 (9) (2018): 77-87.

Thayib. "Spiritual Leadership, Kepuasan Kerja, dan Prestasi Kerja" 16 (2) (2013): 351-82.

Tobroni. The Spiritual Leadership: Pengefektifan Organisasi Noble Industry Melalui Prinsip-Prinsip Spiritual Etis. Malang: UMM Press, 2005.

Uhar Suharsaputra. Administrasi Pendidikan. Bandung: Refika Aditama, 2010.

Umiarso. Kepemimpinan Transformasional Profetik: Kajian Pradigmatik Ontos Integralistik di Lembaga Pendidikan Islam. Jakarta: Prenadamedia Group., 2018.

Veithzal Rivai. Kepemimpinan dan Perilaku Organisasi. Jakarta: Rajawali Pers, 2008.

Yeliz Erath Sirin et. al. "Transformational-Transactional Leadership and Organizational Cynicism Perception: Physical Education and Sport Teachers Sample" 6 (9) (2018): 2008-18. 
Zamroni. ESQ Model E Kepemimpinan Pendidikan: Konstruksi Sekolah Berbasis Spiritual. Semarang: RaSAIL., 2011.

Zulfikri. "Modernisasi Pesantren: Pergeseran Tradisi dan Pudarnya Kyai" 3, no. (2) (2005): 75-94. 